\title{
Krzysztof Jakubiak, Wspóldzialanie rodziny i szkoły w pedagogice II Rzeczypospolitej, Wydawnictwo Uczelniane WSP, Bydgoszcz 1997, ss. 302
}

Pedagogiczna problematyka stosunków rodziny i szkoły wypehnia tę część horyzontu myślenia o kształcie edukacji w dwudziestym stuleciu, która inspiruje, a nawet wymusza, retrospektywne spojrzenie $w$ przeszłość - ku teorii i praktyce związków obu środowisk wychowawczych kreowanych w warunkach polskich przed półwieczem. Rok 1939 stał się bowiem w dziejach Polski momentem zapoczątkowującym destrukcje we wszystkich obszarach egzystencji ludzkiej, zwłaszcza w życiu społeczeństwa i funkcjonowaniu państwa. Po wojnie zaistniała nowa już rzeczywistość polityczna i społeczna, która skutecznie zablokowała „powrót do korzeni" i podtrzymanie tradycji przedwojennej. Edukacja stawała się dogodnym i efektywnym narzędziem osiągania pozapedagogicznych celów. $Z$ każdym rokiem oddalała się od wątków zapoczątkowanych wraz z odzyskaniem w 1918 roku niepodleglości i rozwijanych przez całe dwudziestolecie międzywojenne.

Ślady ewidentnej destrukcji zaznaczyły się także w płaszczyźnie refleksji i rozwiązań praktycznych zwiazanych ze stosunkami rodziny i szkoły. Książka Jakubiaka pt. Wspóldzialanie rodziny $i$ szkoly w pedagogice II Rzeczypospolitej stwarza okazję do dokonania obiektyw. nej oceny rozmiarów i skutków zjawisk negatywnych towarzyszących procesowi przemian tej sfery po 1944 roku. Jest ona nie tylko źródłem dokumentującym stan teorii i praktyki stosunków rodziny i szkoły w okresie międzywojennym, ale pozwala równocześnie wydobyć ważkie i konieczne przesłanki dla transformowania związków rodziny i szkoły u progu XXI wieku.

Intencje autora w warstwach merytorycznej i ideowej sq bardzo ambitne, czego najlepszy dowód stanowia zasadnicze pytania tkwiące u podstaw poszukiwań badawczych (s. 22 - 24). Warto tu jednak podkreślić fakt, iż Krzysztof Jakubiak wpisuje się wyraźnie w krag badaczy usiłujących dzisiaj spożytkować wszystko, co w dorobku pedagogicznym najcenniejsze, a tym samym przydatne w jakoś- ciowo nowej refleksji i rozwiązaniach edukacyjnych. Autor bowiem podziela pogląd, iż „...próbując tworzyc nowy zdemokratyzowany i zhumanizowany kształt stosunków rodziny i szkoły, trzeba nie tylko znać ich dzieje, by krytycznie spojrzeć na dorobek polskiej pedagogiki w tym zakresie w czasach nowożytnych, ale także skutecznie powiązać zagubione w latach powojennych wątki rozwoju historycznego owych stosunków" (s. 12). Wydaje się, iż w takim spojrzeniu zaznacza się swoisty dualizm "duszy" badacza, który świadomie, odpowiedzialnie i kompetentnie stawia siebie $w$ rolach pedagoga i historyka równocześnie.

Lektura książki nie pozostawia nawet cienia złudzen, że mamy do czynienia $z$ pracą historyczna, bazującą na bogactwie źródeł i pozaźródłowej literatury przedmiotu. Jej treści skupione są zatem wokół faktów i zjawisk rzetelnie interpretowanych i ocenianych. Mamy więc do czynienia $\mathrm{z}$ książką zarysowującą monograficznie problematykę stosunków rodziny i szkoły w okresie II Rzeczypospolitej, wypelnioną bogactwem treści oraz, co nie mniej ważne, napisaną komunikatywnie i ciekawie zredagowana. $\mathrm{Z}$ tego punktu widzenia rekomendowana książka stać się może przede wszystkim źródłem podstawowej wiedzy o stosunkach rodziny i szkoły w dwudziestoleciu międzywojennym, inspiracją dla dalszej eksploracji tego zagadnienia, fundamentem do pogłębionej i poszerzonej refleksji nad związkami rodziny i szkoły oraz być może przyczynkiem fachowej dyskusji i sporów w gronie historyków wychowania. $Z$ tej perspektywy jest prawie pewne, iz praca Krzysztofa Jakubiaka stanowi publikację, do której trudno jest odnosić się obojętnie.

Przyglądając się rusztowaniu strukturalno-treściowemu wyłuskujemy cztery zasadnicze aspekty prezentowanych zagadnien. Punkt wyjścia zawiera genezę idei współdziałania rodziny i szkoły w zachodnioeuropejskiej i polskiej myśli pedagogicznej czasów nowożytnych. Tu odnajdujemy zalążki i podstawy myślenia 
o stosunkach rodziny i szkoły oraz ich urzeczywistniania. Dalsze części pracy koncentrują się już na kwestiach samorządnego $\mathrm{i}$ instytucjonalnego współdecydowania społeczeństwa o szkole, stowarzyszeniowego ruchu rodzicielskiego oraz wykreowanego w warunkach Polski międzywojennej modelu współdziałania rodziny i szkoly. W ten sposób Autor dowodzi, iż nastąpiło „istotne przwartościowanie stosunków rodziny i szkoły w dziejach nowożytnych". Książka jako całość stanowi rozwinięcie tezy, że: „Wzajemna obojętność obu środowisk wychowawczych dziecka i wielowiekowa, utrzymująca się od począt ków bieżącego stulecia, uporczywa obrona szkoły przed uczestnictwem rodziców w jej życiu, przeobrażała się systematycznie, choć najczęściej w ograniczonych formach, we współdziałanie" (s. 231). Okres II Rzeczypospolitej na ogół sprzyjał tendencjom usamorządowienia szkoły polskiej (choć Ustawa z 23 lutego 1939 roku o zespoleniu samorządu szkolnego z samorządem terytorialnym budzić może pewne wątpliwości), tworzył warunki dla rozwoju stowarzyszeń i związków rodzicielskich oraz wyzwalał klimat do wypracowania korzystnych form współdziałania rodziny i szkoły. Można przyjąć, iż uwidoczniło się zjawisko pozytywne o cechach zbliżenia rodziny i szkoły ku sobie, integrowania wpływów środowiskowych - w istocie przecież różnych instytucji wychowawczych. Czy jednak mamy do czynienia jedynie $\mathrm{z}$ doświadczeniami dodatnimi?

Krzysztof Jakubiak skoncentrował uwage nie tylko na ewidentnych osiągnięciach. W różnych częściach pracy odnajdujemy odniesienia do niedomagan towarzyszących rozwojowi stosunków rodziny i szkoły. Zdaniem Autora działalność samorządów szkolnych i organizacji rodzicielskich (głównie patronatów) ,....często przebiegała z oporami, miała ograniczony, przede wszystkim do sfer inteligenckich, zasięg społeczny, a relacje między rodzicami i nauczycielami nie były wolne od nieufności, konfliktów i chęci dominacji, szczególnie szkoły" (s. 236). Zresztą już same rozwiązania kwestii samorządu szkolnego nie spelniały oczekiwań działaczy oświatowych i pedagogów. Stowarzyszeniowy ruch rodzicielski nie byl wolny od słabości oraz nie zawsze pozytywnie kształtowały się formy wzajemnych ustosunkowań i relacje pomiędzy uczestnikami współpracy.
Należy jednak mieć na uwadze fakt, iż dotykamy zjawiska i procesu związków rodziny i szkoły kształtowanych zaledwie przez dwie dekady $\mathrm{i}$ to w warunkach społeczeństwa, które odzyskalo swą państwowość po dhugim czasie zaborów. W jakim więc sensie „tymczasowość" porozbiorowych rozwiązań, naśladownictwo dorobku innych społeczeństw, a nawet poszukiwania metodą „prób i błędów" znajduje racjonalne uzasadnienie? Jakie bliskie skojarzenia nasuwaja się wobec sytuacji współczesnych przeobrażeń w stosunkach rodziny i szkoły charakterystycznych dla lat 90-tych? Czy zatem konstatacje Krzysztofa Jakubiaka mogą mieć rzeczywiste znaczenie dla teorii i praktyki relacji omawianych środowisk obecnego czasu transformacji?

Nie tylko mogą mieć, ale i mają - ješli zważyć, iż kwestie uspołecznienia sfery edukacyjnej, w tym także obrazu stosunków rodziny i szkoły, są dzisiaj niezwykle żywotne. Cała przestrzeń edukacyjna zmierza obecnie wraz z całym układem politycznym, społecznym i ekonomicznym ku modelowi demokratycznemu. Chodzi już jednak nie tylko o możliwości wpływu społecznego na edukacje, jej pełne usamorządowienie i wkomponowanie w model zdemokratyzowanego społeczeństwa i państwa, lecz także zarazem o jej zhumanizowanie, co musi oznaczać, iż to nie człowiek jest dla edukacji, lecz ona dla niego; winna mu służyć, otwierać się szeroko na jego możliwości, pragnienia i ideały. Okazuje się, że pierwiastki tego myślenia uobecnily się $w$ teorii $i$ praktyce stosunków rodziny i szkoły okresu II Rzeczypospolitej. Nie zdążyły się jednakże należycie rozwinąć.

Krzysztof Jakubiak zauważa, że chociaż idea wspólnot szkolnych znana była w Polsce, to nie znalazła należytego odbicia $w$ praktyce edukacyjnej (poza próbą J. Jędrychowskiej w Gimnazjum w Pabianicach). W nurcie "nowego wychowania" pojawiły się tendencje do przyznawania uczniom prawa współdziałania z nauczycielami, samorządowej i spółdzielczej aktywności młodzieży, współdecydowania o sprawach szkoły. Nie przeniosły się one jednak na sferę stosunków rodziny i szkoły. Autor omawianej publikacji przywołuje stanowisko J. Chałasińskiego wyrażone w połowie lat 30-tych, które jest symptomatyczne i podnosi 
kluczową dziś kwestię współuczestnictwa dzieci i młodzieży w obszarze relacji $\mathrm{z}$ nauczycielami i rodzicami. Chałasiński przestrzegał wówczas przed zawężaniem tego problemu, „dostrzegał przemijanie zarówno $w$ teorii, jak i w praktyce edukacyjnej problemów współpracy uczniów z nauczycielami, dzieci z rodzicami i młodzieży z dorosłymi w ogóle" (s. 228 - 229). Dzisiaj gdy relacja pedagogicznego współdziałania próbuje przełamywać w teorii i praktyce różnych rodzajów stosunków pedagogicznych (w tym rodziny i szkoły) opory wobec autentycznego partnerstwa dorosłych i dorastajacych, warto do tych myśli i koncepcji sprzed pięćdziesięciu lat powrócić, a niektóre $\mathrm{z}$ nich przemyśleć na nowo.

Jak widać lektura książki Krzysztofa Jakubiaka nie skłania do odłożenia pracy na półkę. Jest to bowiem propozycja intelektualnie płodna $\mathrm{i}$ twórczo inspirująca. Stwarza nie tylko możliwości „rozmowy” z faktami i Autorem, ale także zaznacza swoiście praktyczną użyteczność. Odegra z pewnością istotną rolę w procesie edukacji nauczycielskiej, lecz kto wie czy nie większe znaczenie mieć będzie dla działacza oświatowego czy światłego rodzica. Wszystko zależy od tego czym są dla nas dzisiaj stosunki rodziny i szkoły. Dla Autora książki wydają się być one kluczem odsłaniającym inną, bo bardziej demokratyczną i humanistyczną, optyke ujmowania i rozwiązywania kwestii edukacyjnych. Jestem zdecydowanie po Jego stronie. Pół wieku temu Stanislaw Lisowski wspaniały uczeń wspaniałego pedagoga - Marii Grzegorzewskiej napisał odważnie: „Reforma szkoły właściwie od rozwiązania zagadnienia współpracy domu i szkoły zaczynać się powinna" (Wspólpraca szkoly z domem, NK, Warszawa 1935 , s. 43). Nie znam próby podjęcia tego wyzwania. Podzielam jednak przekonanie tych, którzy spodziewają się w nadchodzącym stuleciu „zwrotu ku czlowiekowi i rodzinie”. Być może wówczas realizacja tego śmiałego postulatu okaże się nie tylko możliwa, ale i efektywna.

Krzysztof Jakubiak w zakończeniu książki formułuje - czyniąc analogie do współczesności - skromną sugestię i proponuje czytelnikowi by uświadomił sobie, „czy myśl innych nie biegła przed laty po podobnych torach". Zdołał w moim przekonaniu tego dowieść. Czy jednak bardziej nie fascynuje niewiadoma dokad owa mysl moglaby nas zaprowadzic?. Nie tylko $\mathrm{z}$ tego powodu warto się prezentowaną tu publikacją zainteresować.

Andrzej W. Janke

\section{Danuta Koźmian, Chrześcijańska myśl wychowawcza Fryderyka Wilhelma Foerstera i jej recepcja w Polsce, Wydawnictwo Uniwer- sytetu Szczecińskiego, Szczecin 1996, ss. 169}

W powojennej historiografii pedagogicznej brakowało dotychczas źródłowego, krytycznego opracowania monograficznego, poświęconego postaci i twórczości Fryderyka Wilhelma Foerstera (1869 - 1966). Książka Danuty Koźmian wypehia tę lukę. Jest ona pierwszą, wydaną po II wojnie światowej rozprawą, która w sposób całościowy ukazuje sylwetke, życie i dorobek tego wybitnego niemieckiego filozofa, pedagoga i moralisty. Autorka dokonuje także udanej próby określenia wpływu pedagogiki F.W. Foerstera na wychowanie chrześcijańskie w Polsce. Celem tej pracy jest bowiem nie tylko dokonanie analizy $\mathrm{i}$ interpretacji myśli wycho- wawczej Foerstera, dotyczącej zwłaszcza wychowania moralnego i obywatelskiego, ale także przedstawienie jej recepcji w Polsce w pierwszej połowie XX wieku oraz określenie możliwości jej wykorzystania we współczesnej pedagogice.

Strukture pracy wyznacza sześć zasadniczych rozdziałów, w ramach których w układzie problemowym, Autorka poddała wszechstronnej analizie historyczno-pedagogicznej wiele szczegółowych zagadnień. W rozdziale pierwszym została ukazana tradycja społecznej i edukacyjnej działalności Kościoła katolickiego w Polsce, ze szczególnym uwzględnieniem jego roli w pracach społeczno-integracyjnych w na- 